\section{Research update}

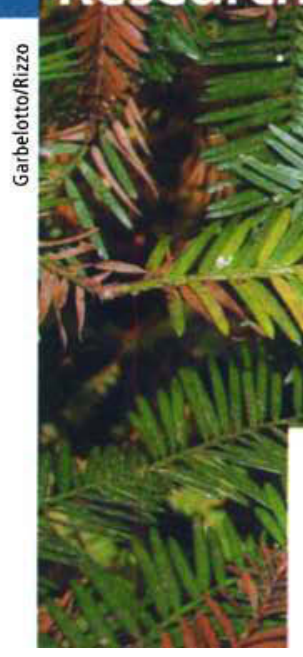

$C$

\title{
SOD pathogen hits coast redwoods, Douglas fir
}

alifornia's prized coastal redwoods and Dou-

glas firs are infected with the same pathogen that causes sudden oak death (SOD), the deadly disease that has killed tens of thousands of oaks along the northern coast of the state, UC scientists reported in September.

Researchers from UC Berkeley and UC Davis have isolated living cultures of Phytophthora ramorum from the branches and needles of coast redwood and Douglas fir saplings that had shown signs of infection. This highly contagious, funguslike disease has now been found in 17 tree species, 16 of which are found in California including madrone, bay laurel and buckeye.

Collaborators UC Davis plant pathologist David Rizzo and UC Berkeley ecosystem scientist Matteo Garbelotto have confirmed its presence in 12 California counties (see map). The disease was first discovered in Marin County oaks 7 years ago.

Garbelotto and Rizzo first announced the discovery of $P$. ramorum DNA in redwoods earlier this year, but couldn't confirm that the pathogen was causing infection until living cultures of it were successfully grown from the field samples.

While the findings may have grave implications for the majestic California redwoods and Douglas fir forests that extend into British Columbia, the researchers have yet to find disease symptoms or death from the pathogen in large, mature redwoods or Douglas fir.

"Although P. ramorum infects redwood saplings and may kill redwood sprouts growing at the base of stumps and adult trees, we don't have any evidence at present that it is killing adult trees," Garbelotto says. "It will take years to know if that is possible."

Each species affected by the disease shows different symptoms, Garbelotto says. In the case of redwoods, the preliminary data suggests the pathogen will infect redwood needles and twigs, as well as portions of the wood. On Douglas fir saplings, the disease causes a tip wilting of both the branches and the terminal shoot.

"It seems that some species are able to tolerate the pathogen better than others," Rizzo says. "We see a whole range of symptoms in the field, from extensive cankers on the trunks of oaks to minor spots on the leaves of the buckeye."

California's coastal redwood and Douglas fir trees are ecologically and economically vital to the state, particularly to the timber, nursery, landscape and construction industries. After the scientists' disclosure, the California Department of Food and Agriculture and USDA Animal and Plant Health Inspection Service (APHIS) immediately added these trees to the official list of susceptible species, making them subject to evolving quarantine regulations. The agencies have regulated movement of redwood and Douglas fir seedlings, needles, twigs and branches less than 1 inch in diameter, from the 12 counties in the official "zone of infestation."

The researchers also conducted DNA tests on diseased sprouts growing from the bases of mature redwood trees in Marin, Alameda, Sonoma, Santa Cruz and Monterey counties. Repeated positive DNA identification strongly suggests the presence of the pathogen in the sampled trees, indicating infection on redwoods may be widespread. Symptomatic and infected Douglas firs, however, have been found only at a single location in Sonoma County to date.

The results were published online in October in the journal Plant Disease. A complete presentation of the data, with analysis by the scientists, will appear in an upcoming issue of California Agriculture.

\section{- Janet White}

The 12 counties where the SOD pathogen has been detected are Humboldt, Mendocino, Sonoma, Marin, Napa, Solano, Contra Costa, Alameda, San Mateo, Santa Clara, Santa Cruz and Monterey. 